\title{
10: 203334234-203329343
}

National Cancer Institute

\section{Source}

National Cancer Institute. 10: 203334234-203329343. NCI Thesaurus. Code C42526.

Physical location of IL10_Gene 